Research Report 1594

\title{
Individual Ready Reserve (IRR) Call-Up: Attitudes, Motivation, and Concerns
}

\author{
Alma G. Steinberg \\ U.S. Army Research Institute
}

Leadership and Motivation Technical Area

Franklin L. Moses, Acting Chief

Training Research Laboratory Jack H. Hiller, Director

U.S. Army Research Institute for the Behavioral and Social Sciences 5001 Eisenhower Avenue, Alexandria, Virginia 22333-5600

Office, Deputy Chief of Staff for Personnel

Department of the Army

June 1991 